\title{
Analysis of Early Childhood Education Teachers Competency in 21st Century in RA Ma'arif Darul Ulum Garut District
}

\author{
Eva Mufaziah $^{1 *}$, Pujiyanti Fauziah ${ }^{2}$, Arti Nurhidayanti ${ }^{3}$ \\ 1,2) Non Formal Education, Universitas Negeri Yogyakarta, Indonesia \\ ${ }^{3)}$ Universitas Pendidikan Indonesia, Bandung - Indonesia \\ *evamuffaziah@gmail.com
}

\begin{abstract}
The purpose of this study was to find out how pedagogical competencies, personal competencies, social competencies and professional competencies of teachers in RA Ma'Arif Darul Ulum Ulum Sinarjaya Village, Bungbulang District, Garut Regency in the 21 st century. The approach in this study uses descriptive qualitative qualitative methods. Data collection techniques using participatory observation, interviews and documentation studies. The subjects in this study were teachers at RA Ma'arif Darul Ulum, Sinarjaya Village, Bungbulang District, Garut Regency with a total of 3 female teachers. Data analysis was performed by data reduction, data presentation, drawing conclusions and verification. The instrument in this study was the researcher himself. The results showed PAUD teachers have Pedagogical, Personality, social and professional Teacher Competencies but did not meet the competence of teachers in the 21 st century so the need to follow and understand the demands of the times, especially the demands of increasingly advanced educational development.
\end{abstract}

Keywords: teachers, competencies, $21^{\text {st }}$ century

\section{Introduction}

In the Industrial Revolution Era in the 21 st Century, students are of course required to master skills and knowledge, especially in the field of technology. Then this becomes a challenge for teachers in the 21 st century by seeing how teacher competencies can support the industrial revolution 4.0 [1]. Are they already in line with developments or are they not yet competent in fulfilling competencies as teachers in their fields?

The development of society in the 21 st century is marked by the rapid development of Science and Technology, so that it affects changes in various aspects of life [2]. For this reason, there has been a change in the education paradigm and trying to improve the quality of education. One of them is early childhood education teacheras education practitioners or teachers must be able to improve and develop their competence in the pedagogical, social, personal and professional aspects. Then the need to analyze in advance the extent to which the teacher paud in his competence as a teacher.

Based on Law No. 14/2005 concerning teachers and lecturers said that, teachers and lecturers are professional positions. While the professional position in question is the teacher has special abilities and has a more special educational background as well. Next Law No.17 / 2007 concerning the qualifications of teacher competency standards [3]. With the competency capabilities of the teacher, can provide an increase in the level of education provided, fostering thinking and understanding of early childhood so as to be able to develop and optimize their 
abilities. There is motivation and development for children so learning is fun and not boring.

In this study, researchers used the theory According to Government Regulation No. 19/ 2005: National Education Standards Chapter VI early childhood education teacher competencies $[4,5]$ includes the ability that must be possessed by teachers, to analyze the ability of teachers in RA Ma'arif Darul ulum Sinarjaya Village, Bungbulang District, Garut Regency regarding four teacher competencies including: Pedagogic, Personality, Social and Professional Competencies.

Pedagogical competencies based on Law.No.19/2005 include: (a) teachers must understand the characteristics, needs, and development of students, (b) Mastering the concepts and principles of education. (c) Mastering the concepts, principles and procedures of curriculum development; (d) Mastering theories, principles, and learning strategies; (e) Creating interactive, informative, fun, challenging learning situations, motivating students to participate, be active, and provide sufficient space for initiative, creativity and independence. (f) Mastering students' concepts, principles, procedures, and tutoring strategies; and (g) Mastering learning media including communication and information technology and $(\mathrm{h})$ Mastering principles, tools and procedures for evaluating learning processes and outcomes.

Personality Competencies include: (a) Presenting oneself as an honest, steady, stable, mature, authoritative and wise and wise person. (b) Having good character and being a role model for students and the surrounding community; (c) Having a democratic spirit, attitude and behavior; and (d) Have the attitude and commitment to the profession and uphold the ethical code of educators.

Social competence includes the ability to be able to: (a) Be open, objective and nondiscriminatory; (b) Communicate and socialize effectively and politely with students; (c) Communicate and get along collegially and politely with fellow tutors and education staff; (d) Empathic and polite communication with parents / guardians of students and surrounding communities. (e) Adapting to local socio-cultural conditions; (f) Collaborate effectively with students, fellow tutors and education staff, and the surrounding community.

Professional competence, including the ability to: (a) Master the substance of aspects of children's development; (b) Mastering the concepts and theories of child development that overshadow the fields of development; (c) Integrate various fields of development; (d) Linking developmental fields with daily life; and (e) Utilizing information and communication technology for personal and professional development.

Slamet Suyanto said that early childhood educators should be professional [6]. early childhood education teacher educators must have a certificate as early childhood education teacher educators in order to be called professional [7]. This is in view of studies which say that early childhood is the foundation for further education. In addition, the early period is a golden period of development of the human brain. For this reason, early childhood educators need to understand the opportunities for maximizing from an early age. Then according to Ahmad Rizali [7] efforts need to be made to improve the quality of education services for early childhood by increasing the quality of early childhood educators.

\section{Research Method}

The approach in research is a qualitative approach using qualitative descriptive methods. The stages of qualitative research include the following steps [8]: (1) Creating a Conceptual Framework, (2) Formulating Research Problems, (3) Sample Selection and Research Limitation, (4) Instrumentation, (5) Data Collection, (6) Data Analysis, (7) Matrix and 
Conclusion Testing. Teachers at RA Ma'arif Darul Ulum, Sinarjaya Village, Bungbulang District, Garut Regency with a total of 3 female teachers.

The instrument in this study was the researcher himself. Made based on the theory taken mainly covers teacher competence. Data collection technique are (1) Participative observation, the researcher made observations in class while learning took place, but did not participate in teaching activities. Just observe the activities carried out by the teacher while learning takes place. (2) Interview, in this study using the type of open standard interview because it uses a set of questions with the standard. Interviews were conducted with students, teachers and peers. (3) Documentation study, to find out teacher competence when in class, the researcher conducted a documentation study including through RPPH that was made and prepared before the implementation of learning took place after that through learning media that were made or used when learning took place and finally the assessment given by the teacher to students using assessments such as What.

Analysis of the data used in the study is data analysis according to Matthew B. Miles and A. Michael Huberman [8] i.e. (a) Data Reduction as a process of selecting, focusing, paying attention, simplifying, abstracting, and transforming rough data arising from field notes, so that the data gives a clearer picture of the results of observations, interviews, and documentation ; (b) Data Display, which is a collection of information arranged to give the possibility of drawing conclusions and taking action. In qualitative research the data presentation is carried out in the form of brief descriptions, charts, tables, graphs, pictograms, and the like. Through the presentation of these data, the data is organized so that it will be more easily understood; (c) Conclusion Drawing or Verification, the researcher makes conclusions based on data that has been processed through data reduction and display. The conclusion drawn is temporary and will change if no strong evidence is found to support the next stage of data collection. However, if the conclusions raised at an early stage are supported by valid and consistent evidence when the researcher returns to the field to collect data, the conclusions presented are credible conclusions.

\section{Results and Discussion}

RA Ma'arif Darul Ulum Foundation is located at Cidahu village, Sinarjaya Village, Bungbulang District one of the early childhood education teacher in Garut Regency. After conducting research, the results of the Competence in RA Ma'arif Darul Ulum are known first, the Pedagogical Competencies of teachers in RA Ma'arif Darul Ulum Sinarjaya Village, Bungbulang District, Garut Regency are as follows:

From the results of the field notes the researchers looked at the competencies held by the teacher regarding this pedagogical competency including: the teacher still lacked understanding of the school curriculum and everything related to the school or academic of a teacher. Researchers observed pedagogical competence in RA Ma'arif Darul Ulum, the object of the study was 3 teachers with two high school graduates and one junior high school who were continuing their education in Package $\mathrm{C}$ and high school but for a teacher sometimes the theory was far apart from reality which is actually. Maybe the education they have is not in accordance with what it should be so that it causes a lack of understanding of aspects of child development, curriculum and many others, by understanding the principles, procedures in providing learning or material to students they care for, care for and students with sincerity and full of love.

Learning is carried out every day not far from learning about reading and writing and counting. Children are fixated on this learning. Furthermore, routine activities are always 
carried out, namely reading iqro (other religions). Teachers only teach to follow children without paying attention to what they should, lack of training of teachers causes limited abilities possessed by teachers so that learning is carried out sometimes not included in the PAUD learning criteria seen and analyzed from each material presented leads to learning to read write and count but that also becomes a demand from parents of students so that their children are given learning that can hone the ability of the calistung to enter further education.

The lack of activeness to participate in the activity of seminars for teachers at the school causes the lack of experience and knowledge gained and the unavailability of book resources that can be used as additional knowledge. Of the three teachers who are the subject of research on the competence of PAUD teachers not yet seen, it can be analyzed from activities carried out on Pedagogical competencies such as understanding the characteristics, needs and development of these students not yet fully mastering and understanding but teachers always try to do the best for students. Teacher Personality Competencies in RA Ma'arif Darul Ulum Sinarjaya Village Bungbulang District Garut Regency have been explained below:

Having a good personal competence is very important for a teacher where a teacher also has a very large role in the education position. How not the teacher is a figure forming the personality of students who pattern students into human beings who have noble character and personal forming of children such as giving examples of good behavior towards students to produce a good generation in the future [2]. A teacher must have sincere affection to educate and care for students like their own children so as to create a comfort and can easily enter into his world. Students will make the teacher a role model and tauldan for him therefore give examples of good behavior or deeds because basically a child will do what they see, will do what he often sees wherever and whenever including when in school, because they have not able to differentiate between good and bad. In addition to being a teacher, the teacher is also a parent of students who must care for and educate children properly and correctly in accordance with what should be. Good behavior of a teacher must be authoritative, wise, fair, cheerful and noble.

Gur professional competence in RA Ma'arif Darul Ulum Sinarjaya Village Bungbulang District Garut Regency after conducting research to three teachers about this competency is the teacher does not understand and does not have an understanding of the substance of aspects of child development, mastering the concept of child development theory overshadow the field of development even though in reality there is a visible effort made by the teacher towards students so that they can develop and be able to optimize their abilities even with the provision of imu that is not in accordance with their current role [7]. To integrate developments in daily life is also not yet understood because of insights into knowledge and sources of knowledge that are not possessed but the teacher always tries to utilize existing media such as mobile phones to find out what is not understood about learning material. From the three teachers who are the subjects of the research it can be concluded about the personality competencies possessed, always present themselves with a friendly attitude, honest responsibility, wise wisdom, fair and always applying and getting used to smiles, greetings and greetings. Because the teacher's personality is a role model for students.

Social Competence in RA Ma'arif Darul Ulum Sinarjaya Village Bungbulang District Garut Regency after making observations is as follows: Humans are social beings because they cannot live alone, humans certainly need other people to complete their lives in order to interact and communicate to do something needed. For example in an education a teacher requires students to do the learning process as well as students need a teacher to be a reference or imitation, a teacher is considered the most great and smartest human by students where they only obey what the teacher says or gives when they being in school. 
The teacher's task is to humanize human beings to change the behavior or attitudes of students towards better and therefore there must be a relationship, interaction or communication between the teacher and students. A teacher is innocent and imitated and therefore gives the best behavior towards students to give birth to a proud and appropriate generation. Social competence is a competency that is very important for teachers because a teacher must be good at interacting and communicating with students, fellow educators, principals, guardians of students and surrounding communities.

Researchers conducted observations on teachers in RA Ma'arif Darul Ulum who are in Sinarjaya village, Bungbulang sub-district, Garut district, regarding social competence. Interaction and communication of teachers in RA both they show appropriate social attitudes and they should do good to students, fellow educators, principals, guardians murida and surrounding communities. It is shown by the attitude of the teacher who always makes eye contact with the students when doing the learning process, mingles and mingles with the students when they are inside and outside the class, integrates and is friendly when there are routine activities that are always carried out in the surrounding environment and always stay in touch with students' parents.

The teacher at RA is also always involved in mutual cooperation activities or monthly routine studies (recitation) and participating in the children's race between districts, communication between schools is well established. In understanding the substance of aspects of child development, curriculum, principles, procedures, etc., cannot yet understand in detail because even the school does not provide adequate learning resources for the teacher. As good and weak as any teacher always does and gives the best because basically. The teacher is a leader in the classroom, the teacher is innocent and imitated. Learners assume that teachers are the most correct they only obey what the teacher says and the teacher teaches.

Being a teacher must have competencies including professional competence where teachers must be able to understand several aspects of development, linking the field of development in their daily lives and utilizing information and communication technology for personal and professional development. However, for the use of this matter has not yet been carried out because indeed in schools the availability of technology, information and communication equipment is not available, therefore the schools only utilize the communication tools they have (mobile phones) to communicate and exchange information and use cameras or videos for certain activities that do require using a mobile phone[3].

When researchers make observations to master the substance of the development aspects of children has not been seen, but there are only a few aspects that begin to be developed and the teacher understands what needs to be done for example in the religious aspects of the teacher accustomed to routinely learning to study the iqro and short prayers. Mastering the concepts and theories of child development that overshadow development fields have not yet been seen or seen because there may be a lack of understanding of them but child development is very much considered according to their abilities, it's just that for the field of development they do not know much because there is no knowledge that the teacher get and manuals that are not available [6]. Guidance or seminars intended for educators or teachers are very rare and have never been followed by teachers in this school and therefore only their last education provision is the material or reference when they carry out learning activities in the classroom. So the teachers must learn a lot, of course especially in facing the challenges of the 21 st century.

Based on the results of the data obtained, there are still many shortcomings or competencies that must be improved again through training on parenting, learning and how teacher competencies can support the learning process in the 21 st century. 


\section{Conclusion}

Based on the results of the analysis in this study, it was concluded that the competencies held by PUAD teachers in the 21st century in Cidahu village, Sinarjaya Village, Bungbulang District, one of the early childhood education centers in Garut Regency were as follows: The teacher had pedagogical competence by showing that he understood the characteristics of students although not fully in accordance with the theory PAUD learning. Due to the irrelevance of the education or educational background of the teacher and the learning so that the material is delivered according to their abilities.

In the personality competencies of the three teachers have displayed good behavior that is appropriate. Having the attitude of ahlakul karimah where the teacher is a role model for students, always mingling and joining students at school or outside school.

In this competency, socialization and interaction are very good, smiles, greetings and greetings are always used to anyone and anywhere. Teachers are also often actively involved in community activities following the culture of the surrounding environment

In the Teacher Competence at RA Ma'arif Darul Ulum this always presents the best for students for example in the academic field, providing understanding of the material until students understand it even though the material presented is not far from learning to read, write and count but seen from the responses given children when learning takes place very well and show changes from before.

\section{References}

[1] Sonia, T. N. (2019). Menjadi Guru Abad 21: Jawaban Tantangan Pembelajaran Revolusi Industri 4.0. http://digilib.unimed.ac.id/38729/

[2] Fatmawati, F., and Setiawati, D. (2018). Pengembangan Kompetensi Guru Sejarah Dalam Menghadapai Tantangan Abad 21. E-Jurnal Mitra Pendidikan, 2(11), 1259-1270.

[3] Mappapoleonro, A. M. (2019). Profesionalisme Guru PAUD Abad 21 dalam Mengembangkan Pembelajaran Kreativitas Anak Usia Dini. Prosiding Seminar Nasional Pendidikan STKIP Kusuma Negara. http:/jurnal.stkipkusumanegara.ac.id/index.php/ semnara2019/ article/view/154

[4] Peraturan Pemerintah Nomor 19 tahun 2005 tentang Standar Nasional Pendidikan. Jakarta: DepartemenPendidikan Nasional.

[6] Ulfah, C., Yuliejantiningsih, Y., \& Soegeng, S. (2017). Pengaruh Kompensasi Dan Motivasi Kerja Terhadap Profesionalisme Guru Paud Di Kecamatan Ungaran Barat Kabupaten Semarang. Jurnal Manajemen Pendidikan (JMP), 5(2). https://doi.org/http://dx.doi.org/10.26877/jmp.v5i2.1935

[7] Christianti, M. (2012). Profesionalisme pendidik anak usia dini. Jurnal Pendidikan Anak, 1(1). https://doi.org/http://dx.doi.org/10.26877/jmp.v5i2.1935

[8] Arikunto, S. (2006). MetodePenelitian. Jakarta: Bina Aksara. 